\title{
Impact of the digital divide on information literacy training in a higher education context
}

\author{
Segarani Naidoo' \\ Durban University of Technology Libraries, Durban University of Technology \\ naidoose@dut.ac.za \\ Jaya Raju ${ }^{2}$ \\ Centre for Information Literacy, University of Cape Town \\ jaya.raju@uct.ac.za
}

\begin{abstract}
Received 22 October 2011
Accepted 25 May 2012

This paper reports on a master's study undertaken to investigate the impact of the digital divide on information literacy (IL) training of Extended Curriculum Programme (ECP) students at the Durban University of Technology (DUT). Since 1994 the demographics of higher education institutions in South Africa have changed. Today these institutions comprise heterogeneous groups of students, by race, economic background, digital background, etc. and consequently with different levels of literacy, information and otherwise. The problem that this study addressed was the impact of having both digitally advantaged and digitally disadvantaged students in the same information literacy classroom, expecting them to reach learning outcomes without frustrating students from either group. The objective of the study was to investigate the impact of the digital divide on IL training of ECP students at the DUT and to recommend guidelines for teaching and learning of IL that would accommodate both digitally advantaged and digitally disadvantaged students. The study employed a mixed method approach in its research design. Data was collected from ECP students (of 2010) by means of a questionnaire; an interview schedule was used to collect data from Subject Librarians involved in teaching the IL module to ECP students; a separate interview schedule was used to collect data from the ECP Coordinator. Qualitative and quantitative data collected were prepared for analysis by means of content analysis and numerical coding, respectively and then subjected to statistical analysis via SPSS, which produced percentage and frequency distributions to ascertain findings. The findings of the study revealed that the digital divide does impact on IL training in ways such as: slowing down the progress of IL lessons; basic computer skills need to be taught in the IL classroom; and that digitally disadvantaged students find it difficult to follow online lessons while advantaged students already have the expertise to access online information. Based on these findings the study recommended computer literacy training should precede IL training and that various creative teaching and learning methods such as group work, online tutorials, games and interactive websites should be incorporated into IL education to accommodate both digitally advantaged and digitally disadvantaged students in the IL classroom.
\end{abstract}

Keywords: Digital divide; higher education; information literacy training

\section{Introduction}

The digital divide refers to the gap that exists between those with ready access to information and communication technology (ICT) tools and those without such access or skills to enable access (Cullen 200I: 3II). In South African higher education (HE) institutions students fall into both these categories. That is, there are some with no such access or skills while there are others who have had access and are skilled in the use of and have vast experience with information and communication technologies (ICTs). Today, learning environments are designed to include web-based technologies and thus the ease of use of these technologies is essential (Brown 2002: 3). However, the South African scenario is such that a large number of HE students are introduced to computers and Internet technology for the first time when they enter these institutions and thus grapple with basic computer skills.

Ojedokun (2007: xiii) points out that the emergence of the information age brought about an interest in information literacy (IL). IL is commonly defined as the ability to: identify the need for information; know the importance of accurate and authentic information; develop search strategies to assist in finding information; source information; evaluate information; use and organise information effectively (Andretta 2005: 15). As with other parts of the world, information literacy education has become a common feature in South African higher HE institutions to help students cope with the information age.

However, in a single IL classroom one may find students who have grown up with technology as well as those who have not used technology before and thus grapple with the use of the mouse, keyboard and other information technology

I. Segarani Naidoo is with the Durban University of Technology Libraries, Durban University of Technology, South Africa.

2. Jaya Raju $(\mathrm{PhD})$ is a Professor at the Centre for Information Literacy, University of Cape Town, South Africa 
tools or resources that need to be mastered in the IL classroom. Hence one may find in an IL classroom a "digital immigrant", that is, a student who was not born into the digital world but who has adopted, or is adapting to, the digital world (Prensky 200I: 3). Prensky (200I: I) describes the "digital native", on the other hand, as a student who has grown up with technology and is thus accustomed to the digital world. The latter term, sadly, does not adequately describe the current South African situation as many current HE students were born in the digital era but not all of them have prior experience or exposure to technologies of today.

Higher education institutions in South Africa have been experiencing a high "failure, repeater and dropout rate" and thus the then Department of Education (DoE - now the Department of Higher Education and Training (DHET)) provided special funding for the Extended Curriculum Programme (ECP) at South African universities (Cape Peninsula University of Technology 2008a). The purpose of introducing the ECP at higher education institutions was to aid struggling students in developing independent learning skills and gaining conceptual knowledge of subjects that they are enrolled for. ECP subjects are not meant to be new subjects but rather extensions to the existing curriculum (Cape Peninsula University of Technology 2008b). The Extended Curriculum Programme at the Durban University of Technology (which was the research site for the study being reported in this paper) includes various modules or interventions some of which include English Communication, End-User Computing, Academic Literacy and Information Literacy (Hlengwa 2005). These modules are not add-on modules, but integrated modules that supplement the skills which students require in their core courses to complete assignments, projects, etc. All teaching and learning are well integrated into mainstream assessments (Naidoo 20I I: 34).

\section{Research problem}

Educational practices in South Africa prior to 1994 (the apartheid era) were racially determined. Hence students attended HE institutions according to race, resulting in these institutions' student bodies being homogenous groups. Patterns of segregation and unequal provisions along racial lines resulted in inequalities between white and black students (Pavlich and Orkin 1993: 1-2). Swartz and Foley (1996: 38) claimed that many of the students entered higher education institutions having been exposed to apartheid designed educational institutions in which they lacked exposure to technology or digital information as these schools were under-resourced (a legacy that continues to impact on South African society to this day). Singh (2004: 4) confirms that apartheid education promoted separate development, providing "inferior" education to "non-whites".

Since 1994 (the new democratic era), however, the demographics of higher institution enrolment in South Africa have changed. Today these institutions comprise heterogeneous groups of students, by race, economic background, digital background, etc. and consequently with different levels of literacy, information and otherwise. The problem that this study addressed was the impact of having both digitally advantaged and digitally disadvantaged students in the same information literacy classroom, expecting them to reach learning outcomes without frustrating students from either group.

The broad objective of this study was to investigate what impact the digital divide has on the information literacy training of ECP students at the Durban University of Technology (DUT) and to recommend guidelines for teaching and learning information literacy that would accommodate both the digitally advantaged and the digitally disadvantaged. The DUT is a historically disadvantaged HE institution in South Africa, currently drawing large numbers of registrations from disadvantaged communities - hence its appropriateness as a research site for this study, the findings of which could find relevance for other HE institutions in South Africa as well. The study's sub-objectives included:

- to identify in what ways the digital divide impacts on the IL training of ECP students;

- to identify innovative teaching and learning methods to accommodate the diversity of students in the IL classroom; and

- to recommend guidelines for teaching and learning IL in the Extended Curriculum Programme that accommodates the digital divide among participating students.

\section{Review of related literature}

While the demographics of HE institution student enrolment in South Africa evolved over the years (mentioned earlier) so too did the educational focus. Education became learner-centred with much of the learning taking place outside the classroom, for example in libraries (Lippincott 2005: I). The library plays a pivotal role in assisting students in gaining lifelong learning skills, for example sourcing information. Higher education is expected to provide students with a wide range of skills and knowledge, for example develop critical thinking skills and cultural and civil value systems and at the end gain a qualification in a specific discipline (Ojedokun 2007:I). Ojedokun (2007: 3) stresses the importance of a quality higher education that would enable a student exiting the institution to contribute to the country's workforce, bringing knowledge and skills into the work environment. He further explains that a knowledgeable and skilled workforce would 
then be able to contribute effectively to the global economy. However, it becomes difficult to produce a knowledgeable and skilled workforce in view of the impact of the digital divide.

In the context of a continuously evolving technological environment, society today demonstrates the need for information skills more than ever before (Fourie and Bothma 2006: 469). However, the information explosion, propelled by the growth of ICTs, aggravates the digital divide. Attewell (200I: 252) posits that the challenges posed by the digital divide are of interest to political, business and government organisations alike. Higher education libraries too, particularly in developing countries, attempt to straddle this divide (Darch and Underwood 1999: 285). Attewell (200I: 252-253) explains that the problem of the digital divide is not confined to developing countries and that access and use of computers are main areas of concern in terms of the digital divide.

While Mutula (2005: 122) posits that the digital divide is a "multi-dimensional phenomenon" involving the divergence of Internet access by developed and developing societies; the gap that exists between the information rich and the information poor; and, the divide that dictates who uses or does not use technology, Salinas (2003: I32) cogently points out that "the digital divide is about people and not computers". Hence while the digital divide may be seen to have varying aspects to it, none of which is less important than the other, this study was concerned with students' abilities to access digital information that is available. In South African HE institutions, largely due to apartheid (as mentioned earlier), there are students from disadvantaged backgrounds who have never used the Internet or students from rural areas who have little or no knowledge of technology. Many of these students have never held a computer mouse, have no keyboard skills and thus teaching them information literacy without addressing these technology problems could prove to be counterproductive. Salinas (2003: 134-135) correctly points out that access to technology is not enough to bridge the digital divide and thus training becomes an important aspect to address this problem. Similarly, Fourie and Bothma (2006: 469) explain that the digital divide is not just about access to ICTs, but about the ability to retrieve information.

Academic libraries are no longer quiet places where students work on assignments and read (Tickle 2009: 7). Today, the academic library is a hub of activity where students use the latest technology, discuss assignments or projects with friends, or study in groups, or connect up to their laptops, or connect to one of the social communication systems, for example, Facebook, e-mail, etc. Tickle (2009: 7) observes that students are no longer "passive receptors of knowledge" but that there is a need to engage them with the latest technology. The concept of the "digital native" (Prensky 200I: I), also referred to as the "Net Generation" (Lippincott 2005: I) or "Generation Y" or "Nintendo Generation" or Millennials" (Manual 2002: 195) may be applied to students who have grown up with computers, cell phones and video games and thus are accustomed to a multimedia environment. These students prefer to figure things out for themselves. Lippincott (2005: I) asserts that these students cannot be expected to passively sit in a classroom learning about accessing information from librarians, learning in a traditional library setting or learning text-based information. Instead, they prefer to learn through gaming, or the use of social networks, for example, Blogs, Twitter, Facebook and other interactive techniques. However, Kennedy et al. (2008: I I8) point out that the integration of ICTs into academic curricula would not necessarily benefit all students. One has to take cognisance of the digital divide. The current environment in which IL training takes place in the South African HE context (as alluded to earlier) includes the "digital native", who cannot be expected to sit in a traditional classroom setting and be instructed in the use of databases, library systems, etc., as well as the digitally disadvantaged student who needs careful guiding and nurturing as he/she may not understand the basics of technology tools, let alone information databases and other advanced library systems.

De Jager and Nassimbeni (2003: 108) attribute the awakening of interest in IL education, beginning in the 1990s, to the influx of information technology. An information literate person is one who has learnt how to learn (Ojedokun 2007: 22 ) as IL is a basic competency needed in the current environment of rapid technological change (Bruce 2002). Andretta (2005: I) reiterates that information literacy is about independent and lifelong learning, with emphasis on knowledge construction. Hence, Ojedokun (2007: 26) sees IL as a critical component of higher education. He also emphasises that integrating IL into academic programmes is the best way to offer IL education. De Jager and Nassimbeni (2005: 34) in emphasising the importance of collaborative efforts between the library and academic departments, argue that partnership in the teaching and learning process between academics and librarians strengthens the links between information literacy, graduate skills and lifelong learning. However, the challenges in the South African higher education context go beyond these universally applicable principles on the delivery of IL education.

Sayed (1998: 83), in his seminal research into IL in South Africa, concluded that historically disadvantaged HE institutions required greater levels of information literacy training than historically advantaged HE institutions. De Jager and Nassimbeni (2002: 168) confirmed that the majority of students in South Africa reach higher education institutions with little or no exposure to libraries and information resources and that they do not have the necessary skills to utilise facilities and resources that are provided at these institutions; hence the need for IL training in higher education institutions is extremely high. But Sayed (1998: 6) cautioned that it is important for IL trainers to be cognisant of the fact 
that students entering higher education institutions in South Africa have not had equal access and exposure to information and technology resources in the different formats. Hence the digital divide, which must have implications for IL training in the higher education context. Thus Lippincott (2005: I) usefully points out that while libraries and the availability of digital information can play an important role in contributing to the education of students, the digital divide has to be addressed first.

\section{Methodology}

The research design entailed a mixed method approach necessary to gather both quantitative and qualitative data required to address the objective and sub-objectives of the study. Quantitative research requiring measurement where aspects of the social world under investigation (ECP students and IL training) had to be accurately and numerically captured (King \& Horrocks 2010: 7), was necessary to identify trends and draw appropriate conclusions. So too was qualitative research which seeks to "understand meanings" and investigate "experience, ideas, beliefs and values" (Wisker 200I: 138) - in this case those of staff and students involved in IL training. This mixed method approach which allowed for harvesting of both quantitative and qualitative data permitted a more comprehensive understanding of the research problem under investigation (Ivankova, Cresswell \& Clark 2007: 263).

Data (both quantitative and qualitative) was collected via a self-administered questionnaire from 227 out of 303 ECP students (75\% return) enrolled in 2010 for information literacy training at DUT. This was triangulated with largely qualitative data collected by means of an interview schedule used to gather data from five out of the six Subject Librarians involved in teaching of the IL module to ECP students, as well as by means of a separate interview schedule used to collect data from the DUT'S ECP Co-ordinator. This triangulation of data collection across populations relevant to the research as well as the use of multiple research techniques to collect data, enhanced not only the richness of the data collected but also its interpretive validity (Maree and Van der Westhuizen 2007: 39-40). A broad array of literature relevant to $\mathrm{IL}$ and the digital divide in the higher education context was consulted to provide insight into aspects that needed to be probed by the data collection instruments. This together with careful pre-testing of the draft instruments ensured the reliability of the research instruments in collecting data necessary to address the objective and sub-objectives of the study.

Qualitative and quantitative data collected were prepared for analysis by means of content analysis and numerical coding, respectively and then subjected to statistical analysis via SPSS ${ }^{\circ}$ Version 18.0), which produced percentage and frequency distributions to ascertain findings.

\section{Findings and discussion}

These are presented in terms of the sub-objectives of the study.

5.1 Impact of the digital divide on the IL training of ECP students

The study sought to identify in what ways the digital divide impacts on the IL training of ECP students.

\section{I. I Secondary education in South Africa}

Of the $65 \%$ of ECP students who claimed that they came from urban-schools, only $57 \%$ believed that these schools were well-resourced while $34 \%$ claimed they came from rural schools and of these only $13 \%$ of these respondents believed that these rural schools were well resourced; an overwhelming $66 \%$ felt that the rural schools that they attended were under-resourced. Singh (2004: 4) confirms that the inequitable school system that existed during the apartheid era, that is, the provision of "inferior education" with lack of adequate learning resources to certain groups, contributed to the digital divide. Thus, many students entering HE institutions were students who had been exposed in some way to "apartheid designed education" (Swartz and Foley 1996: 34) - and this scenario remains largely unchanged nearly two decades later due to the socio-economic challenges facing the country. Hence a report recently released by the Department of Basic Education (20II) reveals that of 593I schools in KwaZulu-Natal, only 4732 schools have libraries and 4939 schools do not have access to computers.

This report supports the findings of this study that many students entering HE institutions in South Africa are likely not to have computer skills or prior technology experience. Therefore it is not an uncommon scenario to find in a higher education setting an IL class comprising of students who come from under-resourced schools as well as well-resourced schools; and this contributes to the disparate digital abilities of ECP students in a single IL classroom. Both Subject Librarians and the ECP Coordinator interviewed in this study, believed that the South African school system contributed to the current digital divide which impacts on students' performance at the tertiary level.

SA Jnl Libs \& Info Sci 2012, 78(I) 


\section{I.2 Level of ICT experience}

Of the $224 \mathrm{ECP}$ students who indicated their level of ICT experience, 148 (66\%) had little or no ICT experience when they first came to the DUT. It is obvious that a significant majority of students entering the tertiary level would experience problems understanding and participating in the IL classroom. Brown (2002: 6) asserts that students who come from disadvantaged backgrounds face huge challenges when entering HE institutions, especially with regard to web-based environments where they are expected to use ICTs. This applies to the IL classroom where students are expected to use online retrieval tools, search databases, use the library online system and other ICTs that they may not have encountered before. Brown (2002: 6) also points out that "computer anxiety" may be experienced by students who lack ICT skills. Students with little or no ICT skills face pressure to develop ICT skills to function in a web-based environment and also to begin to compete effectively with students who are from an advantaged background. Hence students with little or no ICT experience contribute to the digital divide in the IL classroom.

\section{I.3 Computer and Internet access}

The study revealed an equal number of ECP students with access to a computer (50.4\%) at the place where they live while attending university and those with no such access (49.6\%). This inequitable computer access impacts on students' abilities to function effectively in an online environment. For example, those in the IL class who are proficient in the use of computers are likely to become bored with basic computer instructions for the purpose of those students with no access to computers at the place where they live while attending university. The latter often need basic computer training which does not form part of the IL training module. One of the Subject Librarians interviewed observed that disadvantaged students in the IL classroom need individual assistance and need to be nurtured in the use of computers and this often leads to an incomplete syllabus being delivered. For this reason a further four Subject Librarians indicated that the training programme becomes very rushed as a result of the prevailing digital divide and hence their recommendation for more time to teach the IL module. The ECP Coordinator also confirmed that having students with diverse digital expertise in the same classroom poses a problem to teaching IL, especially when the lesson includes online lessons. For example, through boredom those students proficient in the use of computers tend to 'surf the net' and 'play' on social networking tools during the IL lesson while the educator is assisting disadvantaged students with basic computer skills. Digitally disadvantaged students, in the meantime, are likely to experience a degree of anxiety or feelings of inadequacy, especially with being seated together with their digitally advantaged peers in the same IL classroom.

A substantial number (7I\%) of ECP students surveyed did not have access outside of the DUT to a computer with Internet access while only $29 \%$ had such access. A significant part of IL lessons requires knowledge of the Internet. The library online system, databases and online journals are all available via the Internet. Students who have limited Internet access may feel inadequate in the IL classroom, especially when classmates who have access to the Internet outside of the DUT have more Internet experience and thus may sometimes display impatient behaviour in the IL classroom due to the inexperience of those ECP students with limited Internet exposure.

\section{I.4 Level of confidence in using different aspects of the computer and other ICT applications}

De Jager and Nassimbeni (2003: 109) point out that South African students have major disadvantages that might not be experienced by students in the developed world. In keeping with this claim, this study revealed that a significant average of $37 \%$ of the $226 \mathrm{ECP}$ students surveyed on this issue indicated that they were not confident in using different aspects of the computer and other ICT applications and an average of $48 \%$ was unsure of their level of confidence here (see Figure I). Only a small average (9\%) of ECP students surveyed indicated feeling confident or fairly confident in this area. The use of computers is critical to the IL module and yet the majority of ECP students surveyed were not confident in this regard. It is evident that in the IL classroom disadvantaged students are not confident when using different parts of the computer and other ICT applications. This is corroborated by Subject Librarians teaching the IL module who pointed out that disadvantaged students lack basic computer skills, for example, mouse and keyboard skills.

While communication via social networking tools is currently being exploited in all spheres of life, only $48(21 \%)$ of the ECP students surveyed indicated being confident or fairly confident in using social networking applications while a significant number were not confident or unsure of using these applications (see Figure I). Should social networking applications be brought into the learning environment, then surely these students would be further marginalised. Only a small number of ECP students (33(I5\%)) indicated that they were confident or fairly confident in searching the Internet, information databases, the library's online catalogue, etc. and a considerably higher number of ECP students (192(85\%)) indicated that they were not confident or were unsure of searching these facilities (see Figure I). Here again it is evident that there are students in a single IL classroom with differing abilities in using the Internet, information databases and the library's online catalogue - skills that are vital to sourcing information for assignments, projects and other academic tasks. 
These findings reveal that a large number of ECP students lack confidence in using different aspects of the computer and other ICT applications which widens the digital divide.

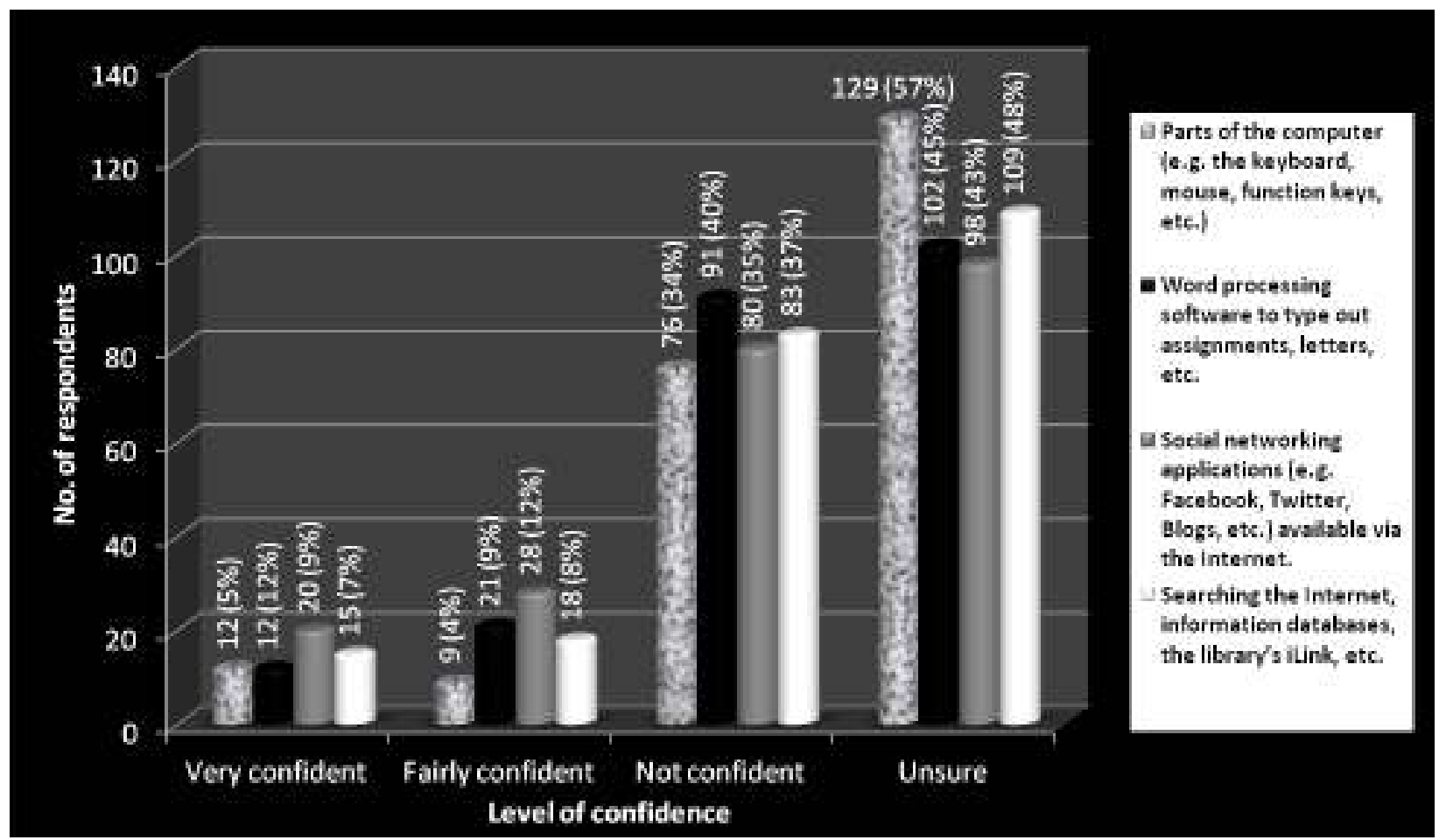

$[\mathbf{N}=\mathbf{2 2 6}]$

Figure 1 Level of confidence in using different aspects of the computer and other ICT applications

\section{I.5 Ways in which the lack of access to ICTs impacts on IL training}

De Jager and Nassimbeni (2003: 108) highlight that higher education institutions are places where students bring with them "previous experiences, beliefs and disciplinary traditions" that may either hinder or assist their progress in the learning environment. It is in this context that they emphasise the importance of acknowledging the disparate experiences of students when developing information literacy activities. Hence it was important to ascertain from the ECP students surveyed ways in which the lack of access for some to ICTs impacted on their IL training at the tertiary level. Figure 2 , which captures these findings, reveals that a significant $35 \%$ of the 226 students who responded to this issue found it difficult to follow online lessons (which make up a substantial part of the IL module at the DUT) because of lack of familiarity with the technology employed in the training, $26 \%$ found most computer terminologies to be new to them and $23 \%$ claimed not to have keyboard skills - a scenario which is indeed a challenge for these students in a learning environment dominated by online lessons. Hence it is not surprising that when ECP students were asked whether they felt disadvantaged in the IL module because of the technology used, an alarming $42 \%$ indicated that they felt somewhat disadvantaged by the technology used in the IL classroom. Salinas (2003: I34), then, quite correctly asserts that providing access to computers does not necessarily ensure equitable technological experience. It is evident from the findings of this study that the technology experiences of ECP students attending the DUT's IL module is by no means equal. Kennedy et al. (2008: 1009) affirm this when they too highlight the different technology experiences of students and the common mistaken assumption that students entering universities are a homogeneous group of 'digital natives'. 


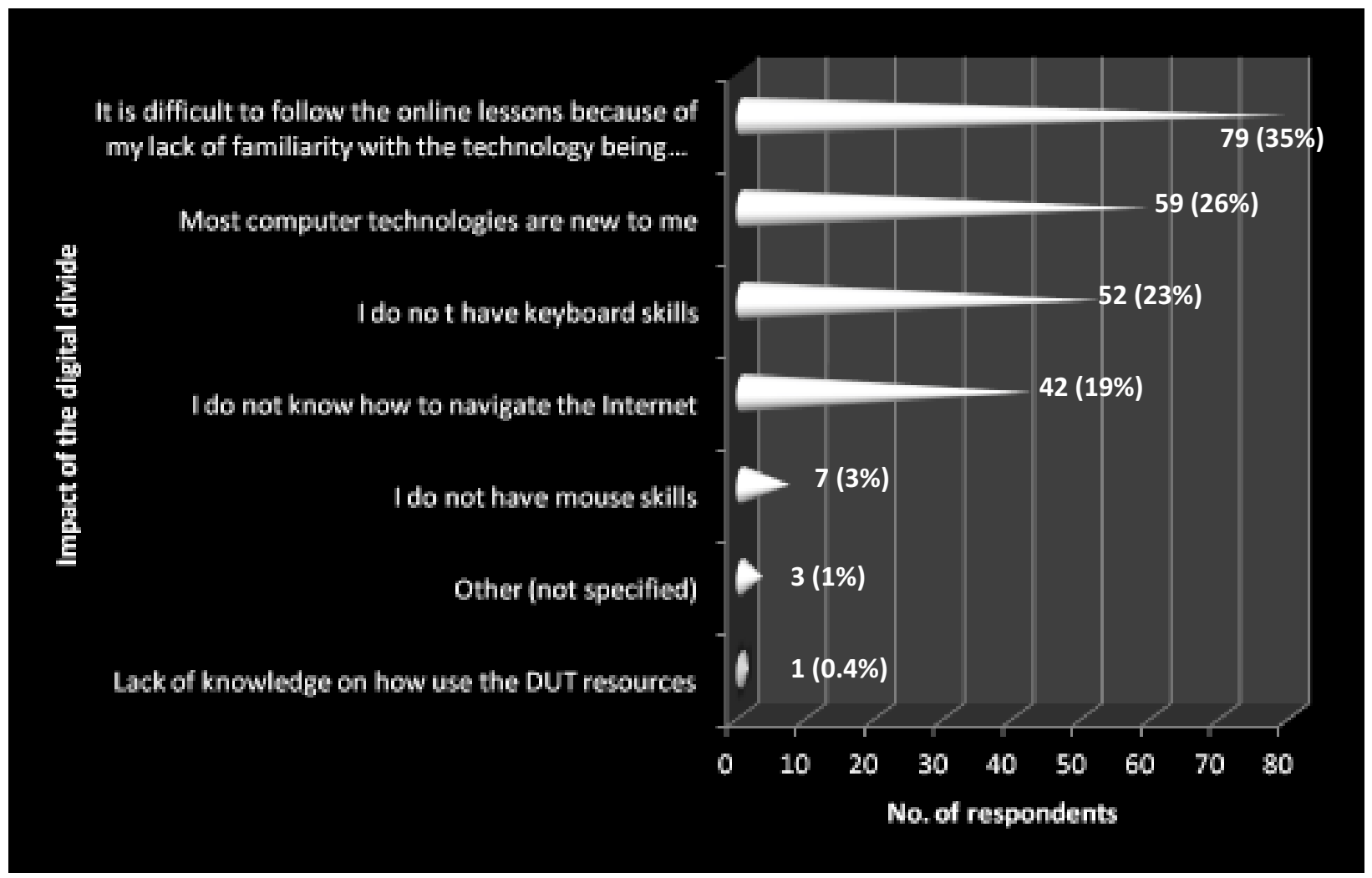

$[\mathbf{N}=\mathbf{2 2 6}]$

Figure 2 Ways in which the digital divide impacts on IL training

\section{I.6 Timing of computer literacy training}

A majority (I46 (65\%)) of the $223 \mathrm{ECP}$ students who responded to this issue indicated that computer training should be offered to digitally disadvantaged students before attending the IL module, with many of them explaining that if basic knowledge of computers is acquired this would allow for less disruption in the IL training module. Both the ECP Coordinator and Subject Librarians concurred with this timing as did evidence from the literature. For example, a study conducted by Blignaut, Venter and Cranfield (2000: 228) demonstrate that a method of bridging the digital divide would be to offer computer literacy to students at the outset. However, an important concern raised by the ECP Coordinator was the process of deciding whether students are digitally disadvantaged or not. The process could create divisions among participating students or create a stigma for certain students which could have a negative effect in the IL classroom. Hence this is an area that needs to be approached with caution and sensitivity.

5.2 Innovative teaching and learning methods to accommodate the diversity of students in the IL classroom Of the $227 \mathrm{ECP}$ students $75 \%$ (168) agreed that creative teaching and learning methods should be used by librarians in the delivery of IL education to accommodate both digitally advantaged and digitally disadvantaged students attending the IL module of the Extended Curriculum Programme. These findings are supported by Lippincott (2005: 3) who suggests that librarians "repackage" IL lessons by revising teaching and learning methods. Among the ECP respondents, the most popular teaching and learning methods were online tutorials where 119 (52\%) ECP students preferred this method; games and group work were the next most popular methods having been selected by 96 (42\%) and 94 (42\%) ECP students, respectively; and lastly, interactive websites as a teaching and learning method was selected by 89 (39\%) respondents. While a less favoured teaching and learning method by ECP students was the traditional chalk and talk (52(23\%)), Subject Librarians believed that chalk and talk as a teaching and learning method is useful for introductory lessons. All interviewees (Subject Librarians and the ECP Coordinator) placed games as a preferred method of teaching and learning in IL education. They described games as a method that could benefit both digitally advantaged and digitally 
disadvantaged ECP students, making all students feel comfortable. Playing games, according to Subject Librarians and the ECP Coordinator, could also help reinforce IL skills that students need to acquire. Surprisingly, while interest in social networking has increased globally there seemed to be a degree of reservation by all three population sets in the use of social networks as a teaching and learning medium. Only $30 \%$ of the ECP students recommended it as a teaching and learning medium to accommodate digitally advantaged and digitally disadvantaged ECP students, yet students are often 'caught' using social networking tools during lessons and in the library. It would seem that students prefer this medium for non-learning purposes.

Subject Librarians indicated, and rightly so, that a combination of methods would serve the needs of all students. For example, while digitally advantaged students work on interactive IL exercises, disadvantaged students may be given more attention with use of technology or with any other aspects they are challenged by. Hence all teaching and learning methods have a role to play in IL instruction and therefore the popular active student-centred teaching and learning methods revealed in the findings (group work, online tutorials, games, interactive websites) need to be creatively used in combination with other tried and tested methods such as the traditional chalk and talk.

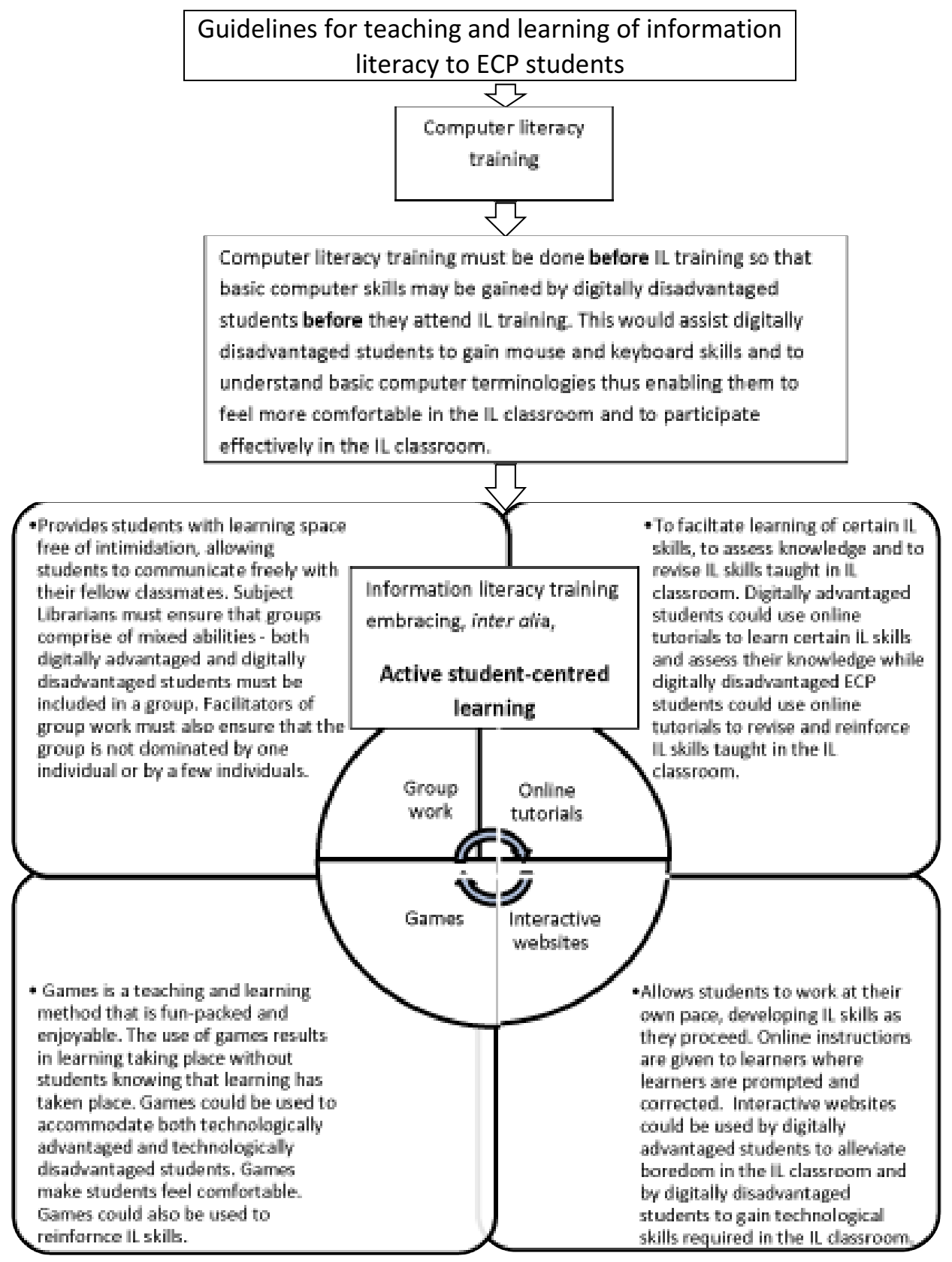

Figure 3 Guidelines for teaching and learning of information literacy to ECP students 
5.3 Guidelines for teaching and learning of IL in the Extended Curriculum Programme that accommodates the digital divide among participating students

Teaching and learning methods to accommodate both the digitally advantaged and the digitally disadvantaged, that featured significantly in the findings of this study included group work, online tutorials, games and interactive websites. While ECP students showed preference for these active student-centred teaching and learning approaches and recommended them to accommodate the digital divide in the IL classroom, Subject Librarians indicated that active student-centred learning in the IL classroom is a realistic goal. Tickle (2009: 7) too emphasises that students need to be engaged in the learning process as they are not "passive receptors of knowledge". Notwithstanding this need for active student learning, Subject Librarians reminded us that chalk and talk still has a place in the IL classroom, albeit selectively. While both Subject Librarians and the ECP Coordinator recommended group work they highlighted the importance of having groups comprised of 'mixed abilities' for meaningful learning to occur. All five Subject Librarians and the ECP Coordinator recommended games as a teaching and learning method to accommodate both the digitally advantaged and the digitally disadvantaged in the IL classroom. Lippincott (2005: 3) asserts that "gaming technology" is useful to accommodate students who are visual learners and games, which involve active learning, is recommended by Manual (2002: 207) to reduce boredom in the IL classroom.

While Lippincott (2005: 4) suggests that librarians develop online tutorials, exercises and guides to reinforce information seeking skills, retrieval and other important IL skills, the ECP Coordinator cautioned, and rightly so, that this method should only be brought in at a later stage when digitally disadvantaged students in the IL classroom have the necessary technological skills - otherwise they would feel further marginalised. In this regard Manual (2002: 196) highlights the importance for librarians to match the instructional style in teaching IL with their student populations. Manual (2002: 196) also opines that students learn better when they are taught in a preferred teaching and learning style. Hence Lippincott (2005: 5) suggests that librarians develop interactive tutorials on the different aspects of the IL module, if this is a method preferred by students. It is evident from these findings and discussion that in order to accommodate both digitally advantaged and digitally disadvantaged students in the IL classroom, active student-centred teaching and learning methods should be embraced, albeit in combination with other teaching and learning methods. Hence the study recommended guidelines (see Figure 3 under Recommendations) for teaching and learning of IL that accommodates the digital divide among participating students.

\section{Conclusions}

The study reported here, which aimed to investigate the impact of the digital divide on information literacy training of ECP students at the DUT and to recommend guidelines for teaching and learning of IL that would accommodate both the digitally advantaged and the digitally disadvantaged, drew the following conclusions:

- The provision of inadequate resources at many secondary schools in South Africa has resulted in under-prepared students arriving at HE institutions. They have little or no ICT experience, which impacts on their participation in IL classrooms, thereby contributing to the digital divide;

- The inequitable access to computers at places where students live while attending university also contributes to differing levels of computer skills and abilities in the IL classroom. Disadvantaged students are faced with a web-based environment where they are expected to exploit available ICTs. They are either not confident with or unsure of the use of different aspects of computers and other ICT applications which impacts on their participation in the IL classroom. Computer and related terminologies are new to them resulting in them finding it difficult to follow online lessons;

- Disparate experience and use of the Internet by students prior to attending university contributes to the digital divide in the IL classroom. In a single IL class there are those who are very experienced in and those who have had little or no prior experience of the Internet;

- A significant number of students feel disadvantaged by technology that is used in the IL classroom which impacts on IL training. IL lessons often include the library automated system, online databases and electronic journals which require students to use web-based technology. Students who feel disadvantaged by the technology used, naturally feel intimidated in such a digital environment;

- Having both the digitally advantaged and the digitally disadvantaged in the same IL classroom impacts on the IL training of ECP students. The IL module is often not completed due to the presence in the same IL classroom of both digitally advantaged and digitally disadvantaged students who require more nurturing and assistance;

- Computer literacy training is critical to acquaint students with basic computer terminologies, and mouse and keyboard skills. Hence, the timing of computer literacy training is very important. Computer literacy training should be offered to ECP students before the IL module;

- Active student-centred teaching and learning methods, such as, group work, online tutorials, games, and interactive 
websites should be used to accommodate both digitally advantaged and digitally disadvantaged students, albeit in combination with other tried and tested methods such as chalk and talk. These active student-centred methods could alleviate boredom on the part of digitally advantaged students and at the same time help digitally disadvantaged students to learn from their advantaged peers or to revise and reinforce lessons covered in the IL classroom; and,

- Librarians should ensure that the method of delivery of IL lessons matches the preferred teaching and learning methods of students. Using the preferred teaching and learning methods could result in better and more effective participation in the IL classroom.

\section{Recommendations}

Guidelines recommended for teaching of IL to ECP students to accommodate the digital divide in the IL classroom, based on the findings and discussion, are captured in Figure 3. Active student-centred learning should be adopted to keep students interested in the IL module and to encourage participation in the IL classroom. Hence the study recommended embracing group work, online tutorials, games and interactive websites as active student-centred teaching and learning methods in IL training but in combination with other relevant teaching and learning methods. A further important recommendation is that computer literacy training should precede information literacy training. The findings and recommendations of this study, while emanating from DUT as a research site, could apply to IL training at other higher education institutions as well. South African higher education student populations are not homogeneous groupings of 'digital natives' but a heterogeneous mix of students with diverse abilities and prior experiences which definitely impact on the teaching and learning environment. Hence the study reported here and its findings have value for the DUT as well as for higher education institutions in South Africa generally.

\section{References}

Andretta, S. 2005. Information literacy: a practitioner's guide. Oxford: Chandos Publishing.

Attewell, P. 200I. Comment: the first and second digital divides. Sociology of Education, 74(3): 252-259.

Blignaut, R.J., Venter, I.M. and Cranfield, D.J. 2000. Fast tracking students from disadvantaged backgrounds into main stream Computer Science. South African Computer Journal/Suid Afrikaanse rekenaartydskrif, 26: 228-23I.

Brown, I.T.J. 2002. Individual and technological factors affecting perceived ease of web-based learning technologies in developing countries. The Electronic Journal on Information Systems in Developing Countries, 9(5): I- I5.

Bruce, C. 2002. The U.S. National Commission on Libraries and Information Science: information literacy as a catalyst for educational change: a background paper. Prague: Czech Republic. [Online]. http://www.nclis.gov/libinter/infolitconf\&meet/ paper/bruce-fullpaper.pdf. Accessed on 28 May 2009.

Cape Peninsula University of Technology. 2008a. Extended Curriculum Programme. [Online]. http://www.cput.ac.za/fundani/ functions/curriculum/foundation.php. Accessed on 16 February 2009.

Cape Peninsula University of Technology. 2008b. Fundani: Extended Curriculum Programme: resources for Extended Curriculum Programme. [Online]. http://www.cput.ac.za/fundani/functions/curriculum/foundation.php. Accessed on 16 February 2009.

Cullen, R. 200 I. Addressing the digital divide. Online Information Review, 25(5): 3I I-320. [

Darch, C. and Underwood, P.G. 1999. Dirt road or yellow brick superhighway? Information and communication technology in academic libraries of South Africa. Library Hi Tech, I7(3): 285-297.

De Jager, K. and Nassimbeni, M. 2002. Institutionalizing information literacy in tertiary education: lessons learned from South African programmes. Library Trends, 5 I (2): 167-I84.

De Jager, K. and Nassimbeni, M. 2003. An exploration of the current status of information literacy tuition in South African tertiary institutions and proposals for curriculum design. South African Journal Of Libraries And Information Science, 69(2): 108II 3.

De Jager, K. and Nassimbeni, M. 2005. Information literacy and quality assurance in South African higher education institutions. Libri, 55: 31-38.

Department of Basic Education (South Africa). 20II. 20II school infrastructure report. [Online]. http://www.education.gov.za/ LinkClick. aspx?fileticket $=h H a B C A e r G X c \% 3 d \& t a b i d=358 \&$ mid $=1802$. Accessed on 24 June $20 \mathrm{II}$.

Fourie, I. \& Bothma, T. 2006. Addressing the digital divide in teaching information retrieval: a theoretical view on taking students from ICT access to knowledge sharing. The Electronic Library, 24(4): 469-489.

Hlengwa, M. 2005. DIT's Foundation Program Report. Durban: Durban Institute of Technology, Centre for Higher Education Development (unpublished).

Ivankova, N.V., Creswell, J.W. \& Clark, V.L.P. 2007. Foundations and approaches to mixed methods research. In Maree, K. (ed.) First steps in research. Pretoria: Van Schaik, pp. 253-282.

Kennedy, G.E., Judd, T.S., Churchward, A. \& Gray, K. 2008. First year students' experiences with technology: are they really digital natives? Australasian Journal Of Educational Technology, 24(I): I08-122.

King, N. \& Horrocks, C. 2010 . Interviews in qualitative research. Los Angeles: SAGE.

Lippincott, J.K. 2005. Net generation student and libraries. Educause Review: Transforming Education Through Information Technology, I-8. [Online]. http://www.educause.edu/educatingthenetgen. Accessed on 08 July 2009.

Manual, K. 2002. Teaching information literacy to Generation Y, 195-2 17. [Online]. http://www.informaworld.com. Accessed on 25 July 2009. 
Maree, K. \& Van der Westhuizen, C. 2007. Planning a research proposal. In Maree, K. (ed). First steps in research. Pretoria: Van Schaik, pp. 23-45.

Mutula, S.M. 2005. Peculiarities of the digital divide in sub-Saharan Africa. Program: Electronic Library And Information Systems, 39(2): I22-I38.

Ojedokun, A.A. 2007. Information literacy for tertiary education students in Africa. Ibadan: Third World Information Services.

Naidoo, S. 20I I. The impact of the digital divide on information literacy training of Extended Curriculum Programme students at the Durban University of Technology. M.Tech. dissertation. Durban: Durban University of Technology.

Pavlich, G. A. \& Orkin, M. 1993. Diversity and quality: academic development at South African tertiary institutions. Johannesburg: CASE.

Prensky, M. 200I. Digital natives, digital immigrants: part I. On the Horizon, 9(5): I-6.

Salinas, R. 2003. Addressing the digital divide through collection development. Collection Building, 22(3): I3I-I36.

Sayed, Y. 1998. The segregated information highway. Cape Town: University of Cape Town Press.

Singh, A.M. 2004. Bridging the digital divide: the role of universities in getting South Africa closer to the global information society. South African Journal Of Information Management, 6(2): I-6.

Swartz, E. \& Foley, P. 1996. Higher education in South Africa: the skills debate. Education + Training, 38(9): 34-40.

Tickle, L. 2009. Academic libraries are undergoing a quiet revolution: being a librarian these days is all about technology and customer service; no time to stick your nose in a book. The Guardian, 18 August 2009, p.7.

Wisker, G. 200I. The postgraduate research handbook: succeed with your MA, MPhil, EdD and PhD. New York: Palgrave. 